\title{
WPEYW MUZYKI NA ZAPAMIĘTYWANIE U OSÓB Z DOŚWIADCZENIEM MUZYCZNYM
}

\author{
Karolina Pius, Natalia Miętus, Agnieszka Olchowik, Iga Parkitna \\ Akademia Pedagogiki Specjalnej im. Marii Grzegorzewskiej \\ ul. Szczęśliwicka 40, 02-353Warszawa
}

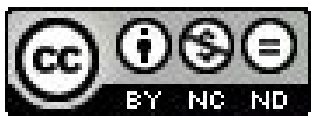

\begin{abstract}
STRESZCZENIE
Artykuł zawiera przedstawienie, a także analizę przeprowadzonego badania, które dotyczyło zapamiętywania oraz odtwarzania materiału neutralnego podczas stuchania muzyki. Przebadano 87 studentów Uniwersytetu Muzycznego im. Fryderyka Chopina w Warszawie. Uzyskane wyniki wskazuja, że badani, słuchający muzyki na etapie zapamiętywania informacji zapamiętują średnio o jedną figurę więcej niż badani, którzy na tym etapie słuchali neutralnego szumu. Nie wykryto istotnych różnic pomiędzy grupami, jeśli chodzi o czas i ilość figur odtworzonych w prawidłowej kolejności. $\mathrm{Na}$ badaną efektywność nauki nie miały również istotnego wpływu takie zmienne jak: doświadczenie i preferencje muzyczne oraz styl nauki.
\end{abstract}

Słowa kluczowe: uczenie się, muzyka, doświadczenie muzyczne, muzycy, teoria podwójnego kodowania Paivio.

\begin{abstract}
This article contains introduction and analysis of a conducted research, which concerns memorizing and recalling neutral material while listening to the music. 87 students of The Fryderyk Chopin University of Music in Warsaw were examined. Received results indicate that subjects who listen to music while memorizing information, on average memorize one item more, than subjects who listen to a neutral noise at the same stage. Concerning the time of performance and correctness of recalled order of items no significant differences were shown between both groups. Efficiency of learning was neither influenced by such variables as: musical experience and preferences, nor learning habits.
\end{abstract}

Key words: learning, music, musical experience, musicians, Paivio's theory of dual coding

\section{WPROWADZENIE}

Pamięć jest zespołem procesów poznawczych umożliwiających zapamiętywanie, przechowywanie i odtwarzanie informacji. W niniejszej pracy oparto się na trzysystemowym modelu pamięci. Zakłada on, iż pamięć podzielić można na trzy „magazyny”, różniące się czasem przechowywania informacji: magazyn sensoryczny, krótkotrwały i długotrwały. Pierwszy z nich odgrywa ważną rolę w percepcji bodźców, przechowując wszystkie informacje postrzegane zmysłami przez kilkaset milisekund. Część dociera następnie do magazynu pamięci krótkotrwałej, gdzie przechowywane są w czasie od kilku do kilkudziesięciu sekund. W pamięci długotrwałej wyselekcjonowane informacje przechowywane są latami, choć dostęp do nich może być ograniczony ${ }^{60}$. Kluczowa w naszym badaniu jest pamięć krótkotrwała, nazwana również pamięcią roboczą. Badacze zwrócili uwagę na to, żejej funkcją jest nie tylko przechowywanie, ale i aktywne przetwarzanie informacji. Odbywa się to dzięki centralnemu systemowi wykonawczemu, który odpowiada za przebieg przetwarzania informacji, rozdzielenie zasobów uwagi zgodnie z realizowanymi w danym momencie zadaniami poznawczymi, oraz kontrolę nad planowaniem i wykonywaniem złożonych zadań poznawczych ${ }^{61}$. Podczas fazy kodowania materiału zapamiętujemy również kontekst jego nabywania, dlatego też łatwiej jest nam przypomnieć sobie materiał $\mathrm{w}$ warunkach podobnych do tych, w jakich był zapamiętywany. Zależność ta nazwana została zasadą „„specyficzności kodowania" ${ }^{2}$. Jeśli chodzi o obecne tendencje w edukacji publicznej, zazwyczaj nie stosuje się dodatkowych bodźców dźwiękowych podczas nauczania. $Z$ tego powodu należy zachować te same warunki podczas testowania wiedzy uczniów, aby uzyskać jak najlepszą efektywność odtwarzania zapamiętanych informacji. Zazwyczaj w tej sytuacji dąży się do zachowania ciszy.

60 E. Nęcka, J. Orzechowski, B. Szymura, Psychologia poznawcza, Warszawa 2013, s. 320- 322.

61 Tamże, s. 349-352.

62 S. M. Kosslyn, R. S. Rosenberg, Psychologia. Mózg. Człowiek. Świat, Kraków 2006, s. 294-320. 
W latach dziewięćdziesiątych ub. wieku narodził się mit tzw. efektu Mozarta ${ }^{63}$. Trzej amerykańscy badacze, na podstawie swoich badań na studentach, ogłosili, że słuchanie jednej z sonat Mozarta przez 10 minut poprawia efektywność wykonywania zadań związanych z rozumowaniem przestrzennym w porównaniu do słuchania dźwięków relaksacyjnych lub ciszy ${ }^{64}$. Wyniki te zostały zgeneralizowane na ogólne zdolności poznawcze. Zaczęto produkować płyty i zabawki dźwiękowe w celu usprawniania inteligencji dzieci65. Późniejsze replikacje badania pozwoliły ustalić źródło efektu Mozarta. Krótkotrwałe pobudzenie, wywołane dźwiękami muzyki klasycznej, wzmagało czujność i pozwalało lepiej wykonywać zadania wymagające wysiłku umysłowego. Jednak efekt ten jest raczej krótkotrwały i może zostać wywołany przez jakikolwiek inny bodziec ${ }^{66}$. W polskich badaniach dowiedziono, że studenci, którzy słuchali muzyki klasycznej byli bardziej ożywieni intelektualnie, zwiększały się ich zdolności twórcze oraz mieli większe poczucie własnej wartości, lepszą koncentrację, skupienie uwagi oraz lepiej zapamiętywali ${ }^{67}$. Zgodnie z teorią podwójnego kodowania Paivio, zapamiętywanie bodźców wzrokowych może być wzmacniane przez stymulację sensoryczną innej modalności. Zauważono, że najlepsze wyniki występuja, gdy ten sam utwór pojawia się w trakcie zapamiętywania oraz odtwarzania ${ }^{68}$. Badania wstępne przeprowadzone przez Kańska, Piwońska, Bajno, Jadczak, Kamińska, Teżewska, Bentkowską i Boguszewskieg ${ }^{69}$ wskazuja, że efekt ten pojawia sięjedynie w odniesieniu do osób posiadających doświadczenie muzyczne. Może mieć to związek z tym, że profesjonalnie wykształceni muzycy mają zwiększoną objętość istoty szarej w obszarze zakrętów Heschla oraz lepsze połączenia międzypółkulowe ${ }^{70}$.

\section{Metoda}

\section{Problem badawczy, zmienne i hipotezy}

Postawiono pytanie badawcze, czy słuchanie muzyki w procesie kodowania informacji ułatwia ich odtwarzanie osobom z wieloletnim doświadczeniem muzycznym?

Zmienną zależną w tym wypadku jest efektywność nauki, mierzona za pomocą wskaźników: czasy odtwarzania informacji, ilość prawidłowo rozpoznanych figur oraz zgodnośćich ustawienia z kolejnościa, w jakiej były prezentowane. Zmienna niezależna to rodzaj prezentowanych dźwięków przy odtwarzaniu informacji. Kontrolowano również takie zmienne, jak: styl nauki (czy badany ma zwyczaj uczyć się przy muzyce), doświadczenie muzyczne (stopień ukończonej edukacji muzycznej) oraz preferencje muzyczne.

Postawiono następującą hipotezę: Słuchanie muzyki podczas nauki ułatwia zapamiętywanie osobom z doświadczeniem muzycznym, jeśli na etapie odtwarzania informacji słyszą tę samą muzykę.

\section{Osoby badane}

W badaniu udział wzięło 87 studentów Uniwersytetu Muzycznego imienia Fryderyka Chopina w Warszawie o średniej wieku około 21 lat (SD 2,04). Około 90\% osób zadeklarowało ukończenie zarówno pierwszego, jak i drugiego stopnia edukacji muzycznej. Wśród badanych znalazło się 49 kobiet oraz 42 mężczyzn, losowo przydzielonych do dwóch grup badawczych: eksperymentalnej, w której na etapie odtwarzania informacji osoby badane słuchały jednocześnie muzyki i kontrolnej, w której odtwarzaniu informacji towarzyszył neutralny szum. W grupie eksperymentalnej znalazły się 24 kobiety i 19 mężczyzn. Grupa kontrolna liczyła 25 kobiet oraz 3 mężczyzn. Wszystkie osoby badane brały udział w losowaniu nagród rzeczowych.

\section{Materiały}

Pomieszczenie, w którym odbyło się badanie, zostało udostępnione przez Uniwersytet Muzyczny imienia Fryderyka Chopina w Warszawie i jednocześnie mogło w nim przebywać 5 osób badanych. Badanie zostało przeprowadzone komputerowo, za pomocą programu Picture Memory (Paweł Boguszewski, 2012) oraz słuchawek zamkniętych (model Sennheiser HD201). Przekątna ekranów komputerów, które zostały użyte w badaniu, wynosiła 15,6".

63 S. O. Lilienfeld, S. J. Lynn, J. Ruscio, B. L. Beyerstein, 50 wielkich mitów psychologii popularnej, Warszawa 2011, s. 88.

64 F. H. Rauscher, G. L. Shaw, K. N. Ky, Music and spatial task performance, "Nature" 1993, nr 365, s. 611.

65 S. O. Lilienfeld, S. J. Lynn, J. Ruscio, B. L. Beyerstein, dz. cyt., s. 88.

66 M. H. Jones, S. D. West, D. B. Estell, The Mozart effect: Arousal, preference, and spatial performance, "Psychology and Aesthetics" 2006, nr 1, s. $26-32$.

67 E. Czerniawska, Wptyw muzyki na efektywność procesów pamięciowych, „Ruch Pedagogiczny”2008, nr 1-2, s. 35-47.

68 E. Czerniawska (red.), Pamięć. Zjawiska zwykte i niezwykte, Warszawa 2005.

69 M. Kańska, J. Piwońska, P. Bajno, A. Jadczak, M. Kamińska, D. Teżewska, K. Bentkowska, P. Boguszewski, Wpływ muzyki na zapamiętywanie sekwencji bodźców, Referat wygłoszony na III Ogólnopolskiej Studencko - Doktoranckiej Konferencji Naukowej Psychodebiuty, Kraków 2012.

70 P. Schneider, M. Scherg, H. G. Dosch, H. J. Specht, A. Gutschalk, A. Rupp Morphology of Heschl's gyrus reflects enhanced activation in the auditory cortex of musicians, "Nat Neurosci" 2002, No 5, s. 688-694. 


\section{Picture Memory}

Informacja na ekranie instrukcji zapoznaje osobę badaną z kolejnymi etapami badania, instruuje o zachowaniu ciszy i założeniu słuchawek. Dodatkowo badani proszeni byli o nieingerowanie w głośność słyszanych dźwięków. Program zawiera ekran ankiety, która na pierwszym etapie umożliwia zebranie podstawowych danych na temat edukacji muzycznej, preferencji muzycznych oraz zwyczajów podczas nauki. Trzeci etap badania to trzykrotne odtwarzanie sekwencji bodźców wzrokowych, które mają zostać zapamiętane przez osobę badaną. Ostatni etap to ich przypominanie. W naszym badaniu spośród 20 neutralnych symboli wzrokowych ${ }^{71}$ należało wybrać i uporządkować 9 , które zostały wcześniej zaprezentowane. Dodatkowo, na obu etapach istnieje możliwość jednoczesnej prezentacji bodźca dźwiękowego. W naszym badaniu wykorzystany został trwający 56 sekund fragment utworu Tahiti Trot, Op. 16 Tea for two skomponowany przez Dmitri Shostakovicha oraz różowy szum (szum 1/f). Wybrany utwór Shostakovicha w badaniu Kańskiej i in. został uznany przez sędziów kompetentnych za neutralny pod względem nastroju wzbudzonego u słuchającej osoby. Ze względu na to, że w niniejszym badaniu korzystano z tego samego programu komputerowego i puli neutralnych symboli wzrokowych, postanowiono nie zmieniać tego elementu. Do warunku kontrolnego został natomiast dodany różowy szum - wrażenie słuchowe powstające dzięki długotrwałej fali akustycznej o zmiennej częstotliwości, którego widmowa gęstość mocy jest zbliżona do widmowej gęstości mocy dźwięków występujących w naturze. Na ogół jego odbiór jest neutralny, w przeciwieństwie do szumu białego, który częściej określany jest jako nieprzyjemny ${ }^{72}$.Wykorzystanie w eksperymencie różowego szumu jest alternatywą dla warunku, w którym wykorzystany jest utwór muzyczny. Dzięki temu możemy założyć, że wszystkie osoby badane przebywały w podobnych warunkach akustycznych. Nie byłoby to możliwe, gdyby na etapie przypominania w grupie eksperymentalnej oraz zapamiętywania i przypominania w grupie kontrolnej dźwięków nie było wcale. Głośność wykorzystanych dźwięków mieściła się w granicach 40- 50 decybeli.

Rysunek 1. Instrukcja przekazywana osobom badanym w programie Picture Memory.

\section{Informacje o badaniu}

Badanie testuje skuteczności zapamiętywania podczas słuchania muzyki. Wstęp: Zanim przystąpisz do eksperymentu:

1. Wypełnisz test dotyczący zainteresowanie muzyką i podstawowych danych (wiek i płeć)

2. W drugim etapie będziesz mógł potrenować sposób wpisywania w odpowiedniej kolejności znaków - ta sama metoda będzie użyta w czasie właściwego eksperymentu (etap 4).

\section{Eksperyment:}

1. W pierwszej części badania trzykrotnie zostanie wyświetlonych pokaz - 9 elementów graficznych wyświetlanych jeden po drugim w rytm muzyki.

2. W tej części badania wybierz spośród 20 znaków te, które widziałeś $w$ części pierwszej w takiej kolejności, w jakiej zostały one zaprezentowane.

Jeżeli jesteś gotowy, kliknij przycisk DALEJ

\section{DALEJ}

71 T. A. Salthouse, The processing-speed theory of adult age differences in cognition, "Psychological Review" 1996, № 103, s. 403-428.

72 S. Kogan, Electronic Noise and Fluctuations in Solids, Cambridge 1996, s. 203-283. 
Rysunek 2. Okno ankiety w programie Picture Memory

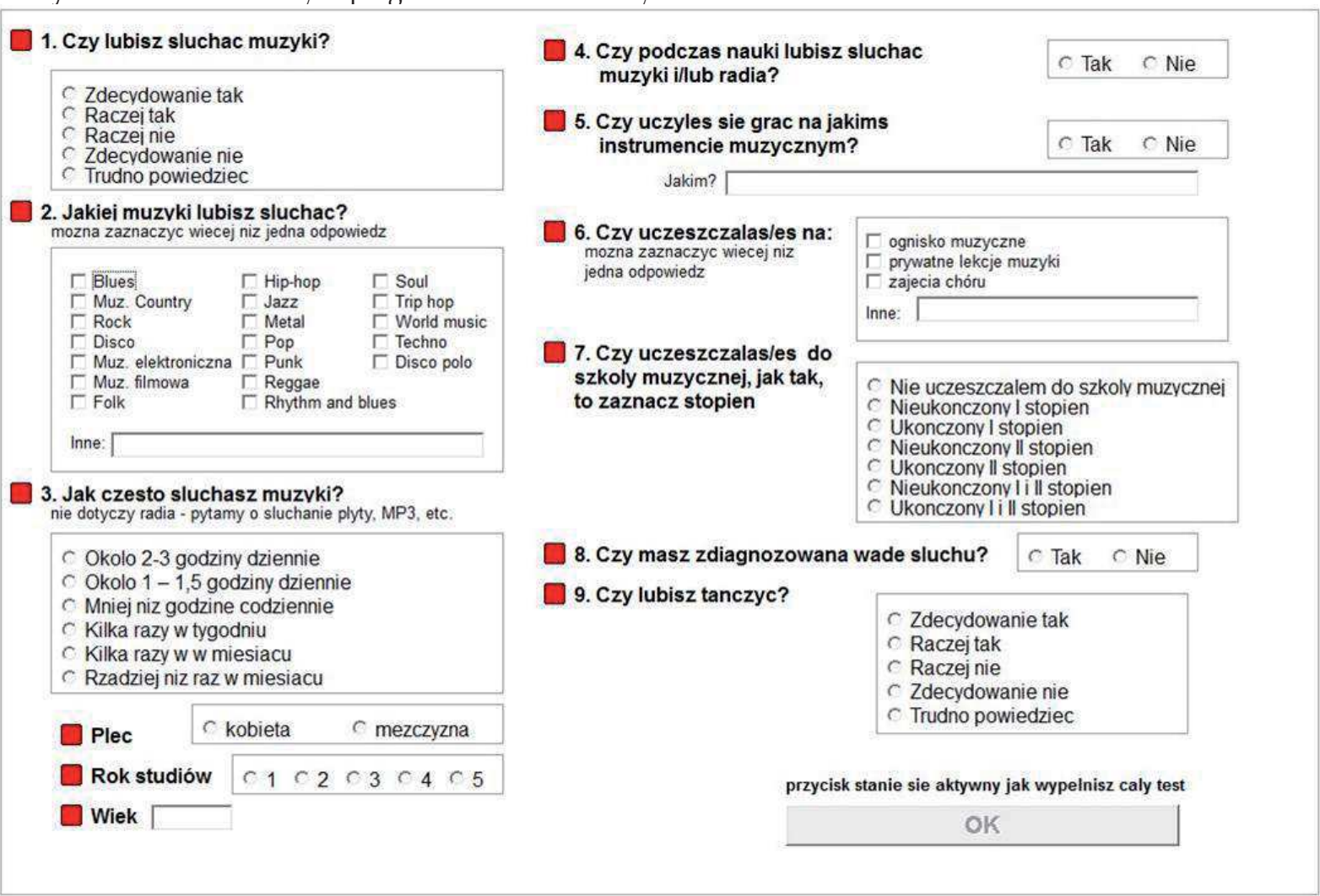

Rysunek 3. Okno końcowe- odpamiętywanie sekwencii bodźców w programie
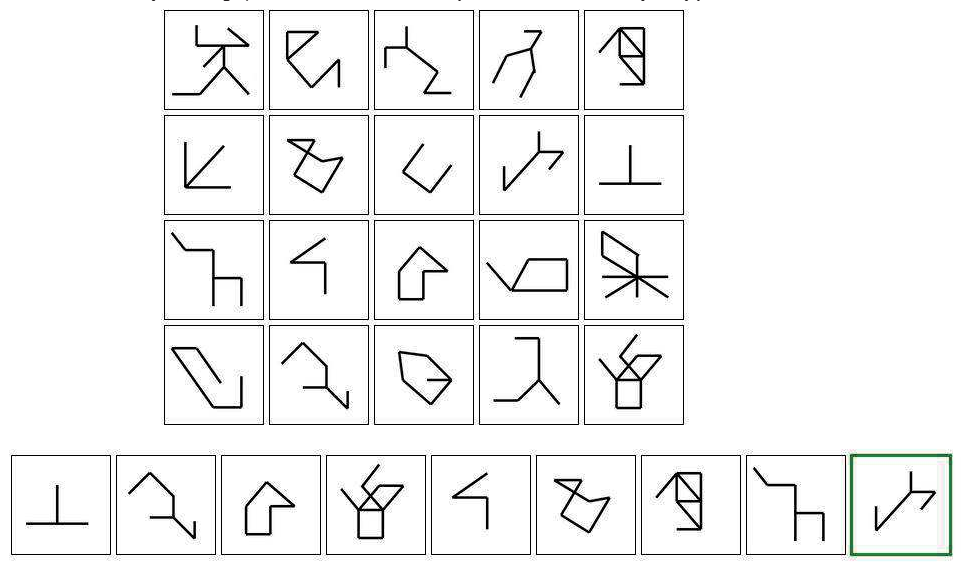

KONIEC

\section{Procedura}

Po wejściu do sali osoby badane były losowo przydzielane do jednej z dwóch grup badawczych: eksperymentalnej, w której zapamiętywaniu symboli wzrokowej towarzyszyła muzyka i kontrolnej, w której na etapie zapamiętywania badani słyszeli neutralny szum. Eksperymentator zakodował odpowiedni warunek w wykorzystywanym programie, a osoby badane zapoznawały się z instrukcją badania. Następnie uzupełniały ankietę dotyczącą podstawowych danych, wykształcenia muzycznego i preferencji muzycznych. Po uzupełnieniu ankiety następował trening wpisywania symboli.

Po zakończeniu treningu następowało badanie właściwe. Jego pierwsza część polegała na trzykrotnym odtworzeniu sekwencji 9 neutralnych symboli wzrokowych.

W grupie eksperymentalnej prezentacji symboli towarzyszył utwór Tahiti Trot, Op. 16 Tea for two, natomiast w grupie kontrolnej dźwiękiem towarzyszącym prezentacji symboli był różowy szum. Część druga polegała na przypominaniu prezentowanych wcześniej bodźców. Zarówno w grupie eksperymentalnej, jak i kontrolnej, osoby badane wykonując 
zadanie, słyszały różowy szum. Pod uwagę brana była liczba prawidłowo rozpoznanych symboli oraz prawidłowo przypomniana kolejność ich prezentacji.

\section{WYNIKI}

Analiza testem t-Studenta wykazała istotne statystycznie różnice pomiędzy grupami pod względem ilości prawidłowo rozpoznanych figur. Badani z grupy, w której w etapie uczenia się sekwencji figur słuchali muzyki, zapamiętywali średnio o jedną figurę więcej, niż osoby z grupy, w której wtedy słyszeli szum. W pozostałych wskaźnikach efektywności nauki nie zaobserwowano różnic istotnych statystycznie (Tabela 2).

Nie wykazano również różnic istotnych statystycznie pod względem efektywności nauki w podziałach na grupy według preferencji muzycznych oraz zwyczajów podczas nauki („Czy podczas nauki lubisz słuchać muzyki lub radia?”).

Analiza korelacyjna nie wykazała istotnych statystycznie różnic pomiędzy doświadczeniem muzycznym badanych a efektywnością nauki.

Tabela 1. Średnie wartości dla zmiennej efektywność nauki z podziałem na grupy eksperymentalną i kontrolną.

\begin{tabular}{lllll}
\hline wskaźniki efektywności & warunki odtwarzania & $\mathrm{N}$ & średnia & odchylenie standardowe \\
\hline \multirow{2}{*}{ czas odtwarzania } & muzyka & 40 & 83490,33 & 34338,21 \\
\cline { 2 - 5 } & Szum & 47 & 75212,47 & 35200,75 \\
\hline \multirow{2}{*}{$\begin{array}{l}\text { ilość prawidłowo rozpoznanych figur } \\
\text { ilość figur odtworzonych }\end{array}$} & Muzyka & 40 & 8,63 & 0,54 \\
\cline { 2 - 5 } w poprawnej kolejności & Szum & 47 & 7,51 & 1,97 \\
\hline
\end{tabular}

Tabela 2. Porównanie średnich pomiędzy grupą eksperymentalną i kontrolną pod względem efektywności nauki.

\begin{tabular}{llll}
\hline wskaźniki efektywności & $\mathrm{t}$ & $\mathrm{df}$ & różnica średnich \\
\hline czas odtwarzania & 1,106 & 85 & 8277,86 \\
\hline ilość prawidłowo rozpoznanych figur & 3,725 & 54,020 & $\mathbf{1 , 1 1 *}^{*}$ \\
\hline ilość figur odtworzonych w poprawnej kolejności & $-0,051$ & 85 & 0,02 \\
\hline
\end{tabular}

${ }^{*} \mathrm{p}<0,01$ (dwustronnie)

Tabela 3. Macierz korelacji pomiędzy zmiennymi efektywność nauki i doświadczenie muzyczne.

\begin{tabular}{lllll}
\hline & & $\begin{array}{l}\text { ilość prawidłowo } \\
\text { rozpoznanych figur }\end{array}$ & czas & $\begin{array}{l}\text { ilość figur odtworzonych w poprawnej } \\
\text { kolejności }\end{array}$ \\
\hline \multirow{2}{*}{$\begin{array}{l}\text { Stopień szkoły } \\
\text { muzycznej }\end{array}$} & $\begin{array}{l}\text { Korelacja } \\
\text { Pearsona }\end{array}$ & $-0,084$ & $-0,131$ & 0,110 \\
\cline { 2 - 5 } & $\begin{array}{l}\text { Istotność } \\
\text { (dwustronna) }\end{array}$ & 0,437 & 0,226 & 0,312 \\
\hline
\end{tabular}

\section{DYSKUSJA}

Jak podaje literatura, najlepsze wyniki w nauce występuja, gdy na etapie zapamiętywania i odtwarzania występuje ten sam utwór ${ }^{73}$ Badania wstępne wskazuja, że efekt ten pojawia sięjedynie wśród osób z doświadczeniem muzycznym. Podczas nauki zapamiętujemy nie tylko materiał, ale również kontekst, w jakim się on znajduje ${ }^{74}$. Wyjaśnieniem otrzymanych wyników może być teoria podwójnego kodowania Paivio. Badania własne wskazuja, że badani z grupy, w której w etapie uczenia się sekwencji figur, słuchali muzyki, zapamiętywali średnio o jedną figurę więcej, niż osoby z grupy, które słyszały wtedy szum. Zatem można przyjąć, że pomimo różnych warunków przy uczeniu się i odtwarzaniu informacji muzycy również wtedy zapamiętują informacje lepiej. Jak pokazują badania neuronalne, wyjaśnieniem tej zależności może być

73 E. Czerniawska, dz. cyt., s. 35-47.

74 S. M. Kosslyn, R. S. Rosenberg, dz. cyt., s. 292-339. 
specyfika budowy mózgu muzyków. Badania Schlauga ${ }^{75}$ i Schneidera ${ }^{76}$ pokazuja, że osoby profesjonalnie wykształcone muzycznie mają większą objętość istoty szarej w obszarze zakrętów Heschla oraz lepsze połączenia międzypółkulowe, co może ułatwiać odtwarzanie.

Badania Schellenberga ${ }^{77}$ wykazały również, że ulubiona muzyka może poprawić nastrój, a to ma związek z tymczasowym pobudzeniem. W stanie relaksu i odprężenia, na który wpływa muzyka, można osiągnąć lepsze wyniki w nauce. Niewykluczone, że muzyka wpływa również na koncentrację i uwagę badanych. Przypuszczalnie osoby badane- wykształceni muzycy, kojarzyli muzykę z pewnym rodzajem pobudzenia i w związku z tym osiągnęli wyższe wyniki w grupie, w której etapowi uczenia się towarzyszyły określone dźwięki.

Warto zwrócić uwagę na fakt, że kontakt z muzyką na wczesnym etapie życia ma związek z rozwojem funkcji intelektualnych. Badania przeprowadzone na sześciolatkach, które uczyły się gry na instrumencie klawiszowym lub miały lekcje śpiewu wskazują, że dzieci te są bardziej inteligentne niż ich rówieśnicy. Wykształceni muzycy mają częsty kontakt z muzyką już w wieku dziecięcym i dużą wprawę w wykonywaniu zadań, podczas słuchania muzyki. Ich uwaga jest w tym zakresie bardziej elastyczna i podzielna niż u osób bez doświadczenia muzycznego. ${ }^{78} \mathrm{~W}$ związku z tym przypuszczalnie będą osiągali wyższe wyniki na etapie odtwarzania informacji w zadaniach, którym będą towarzyszyły określone dźwięki. Jednak niektóre badania nie wykazały istotnych statystycznie różnic pomiędzy doświadczeniem muzycznym badanych a efektywnością nauki ${ }^{\text {79 }}$.

Wyniki w pozostałych wskaźnikach efektywności nauki okazały się nieistotne. Może mieć to związek z tym, że w procesie zapamiętywania występowania bodźców ma udział pamięć deklaratywna, natomiast w zapamiętywaniu kolejności wystąpienia figur badani musieli posłużyć się pamięcią roboczą. Ustawienie sekwencji bodźców wymaga pewnych operacji myślowych. W niniejszym badaniu osoby miały możliwość w procesie odtwarzania manipulowania kolejnością figur, zanim podjęli decyzję, że wybrane ustawienie jest prawidłowe. Również inne badania wskazuja, że edukacja artystyczno-muzyczna może poprawiać pamięć robocza, wzrokowa, werbalną oraz funkcje wzrokowo-przestrzenne ${ }^{80}$. Badania Elyse i Donny ${ }^{81}$ wskazuja, że długotrwała edukacja muzyczna jest związana z poprawą pamięci roboczej, zarówno w obszarze dźwiękowym, jak i wizualnym. Okazuje się, że wyniki w prezentowanym badaniu różnią się od tych, które zostały przedstawione przez wymienionych badaczy.

Brak istotnych różnic międzygrupowych w czasie wykonania zadania mógł być spowodowany brakiem informacji o mierzeniu czasu. Może gdyby badani otrzymali taki komunikat, mieliby większą motywację do szybszych decyzji co do poprawności ustawienia figur.

W przyszłych replikacjach badania, warto byłoby dodać również trzecią grupę, w której w procesie uczenia się i odtwarzania w sluchawkach prezentowany byłby szum.

Z pewnością muzyka jest czynnikiem wpływającym na procesy poznawcze, inteligencję oraz jest walorem kształtującym osobowość i wrażliwość emocjonalną. Przeprowadzone badania wykazały istotne statystycznie różnice pomiędzy doświadczeniem muzycznym badanych a efektywnością nauki jedynie w zapamiętywaniu informacji, natomiast nie wykazały związku muzyki z ułatwianiem przeprowadzania operacji na materiale niewerbalnym. Literatura jednak nie dostarcza jednoznacznych wniosków co do wpływu muzyki na zapamiętywanie. W związku z tym zagadnienie to warto byłoby zweryfikować $\mathrm{w}$ badaniach w przyszłości.

\section{BibliOgRAFIA:}

[1] Cohen M. A., Evans K. K., Horowitz T. S., Wolfe J. M, Auditory and visual memory in musicians and nonmusicians, „Psychonomic Bulletin \& Review" 2011, vol. 18, No 3.

[2] Czerniawska E. (red.), Pamięć. Zjawiska zwoykłe i niezwykłe, Warszawa 2005.

[3] Czerniawska E., Wpływ muzyki na efektywność procesów pamięciowych, „Ruch Pedagogiczny” 2008, nr 1-2.

[4] Elyse M. G., Donna C., Music training and working memory: An ERP study, „NNeuropsychologia” 2011, T. 49, nr 5.

75 G. Schlaug, J. Jancke, Y. Huang, J. F. Staiger, H. Steinmetz, Increased corpus callosum size in musician „Neuropsychologia” 1995, No 33, s. 1047-1055.

76 P. Schneider, M. Scherg, H. G. Dosch, H. J. Specht, A. Gutschalk, A. Rupp, dz. cyt., s. 688-694.

77 E. G. Schellenberg, Music and Cognitive Abilities, "Current Directions in Psychological Science” 2005, No 14, s. 317-320.

78 J.A. Sloboda, Umyst muzyczny: poznawcza psychologia muzyki, Warszawa 2002.

79 M. A. Cohen, K. K. Evans, T. S. Horowitz, J. M. Wolfe, Auditory and visual memory in musicians and nonmusicians, "Psychonomic Bulletin \& Review" 2011, vol. 18, № 3, s. 586-591.

80 M. R. Rueda, M. K. Rothbart, B. D. McCandliss, L. Saccomanno, M. I. Posner, Training, maturation, and genetic infuences on the development of executive attention, "National Academy of Sciences" 2005, No 102, s. 41.

81 M. G. Elyse, C. Donna, Music training and working memory: An ERP study, „Neuropsychologia” 2011, T. 49, nr 5, s. 1083-1094. 
[5] Jones M. H., West S. D., Estell D. B., The Mozart effect: Arousal, preference, and spatial performance, "Psychology and Aesthetics" 2006, No 1.

[6] Kańska M., Piwońska J., Bajno P., Jadczak A., Kamińska M., Teżewska D., Bentkowska K., Boguszewski P., Wpływ muzyki na zapamiętywanie sekwencji bodźców, Referat wygłoszony na III Ogólnopolskiej Studencko - Doktoranckiej Konferencji Naukowej Psychodebiuty, Kraków 2012.

[7] Kogan S., Electronic Noise and Fluctuations in Solids, Cambridge 1996.

[8] Kosslyn S. M., Rosenberg R. S., Psychologia. Mózg. Człowiek. Swiat, Kraków 2006.

[9] Lilienfeld S. O., Lynn S. J., Ruscio J., Beyerstein B. L., 50 wielkich mitóww psychologii popularnej, Warszawa 2011.

[10] Nęcka E., Orzechowski J., Szymura B., Psychologia poznawcza, Warszawa 2013.

[11] Rauscher F. H., Shaw G. L., Ky K. N., Music and spatial task performance, "Nature" 1993, No 365.

[12] Rueda M. R., Rothbart M. K., McCandliss B. D., Saccomanno L. and Posner M. I., Training, maturation, and genetic influences on the development of executive attention, "National Academy of Sciences" 2005, No 102.

[13] Salthouse T. A., The processing-speed theory of adult age differences in cognition, "Psychological Review" 1996, No 103.

[14] Schellenberg E. G., Music and Cognitive Abilities, „, Current Directions in Psychological Science” 2005, No 14.

[15] Schlaug G. , Jancke J., Huang Y., Staiger J. F., Steinmetz H., Increased corpus callosum size in musician „Neuropsychologia” 1995, nr 33.

[16] Schneider P., Scherg M., Dosch H. G., Specht H. J., Gutschalk A., Rupp A., Morphology of Heschl's gyrus reflects enhanced activation in the auditory cortex of musicians, "Nat Neurosci" 2002, No 5.

[17] Sloboda J. A., Umyst muzyczny: poznawcza psychologia muzyki, Warszawa 2002. 